\title{
Medical Milestones
}

\section{Sanitation: pragmatism works}

BMJ 2007; 334 doi: http://dx.doi.org/10.1136/bmj.39044.508646.94 (Published 04 January 2007) Cite this as: BMJ 2007;334:s17

Johan P Mackenbach, professor of public health j.mackenbach@erasmusmc.nI

${ }^{1}$ Department of Public Health, Erasmus MC, University Medical Center Rotterdam, PO Box 2040, 3000 CA Rotterdam, Netherlands

Despite erroneous theories of disease causation and the lack of an evidence base, new sewage disposal and water supply systems in the 1800 s revolutionised public health in Europe

At some time in the 1780s the Industrial Revolution began-firstly in Britain then in other European countries. Technical and commercial advances enabled European societies to break through their preindustrial production ceiling, initiating the seemingly limitless multiplication of goods and services. Expanding industry attracted labourers and their families to towns and cities, which grew rapidly, at the expense of rural areas. In terms of economic output these transformations were an immense success; in terms of human wellbeing they were not. Unplanned urbanisation, appalling working conditions, and low wages led to a deterioration in the health of much of the population. In Britain, where these changes occurred first and most rapidly, average life expectancy at birth actually declined during the first half of the 19 th century. 1

Infectious diseases exacted a huge toll in morbidity and mortality, among them tuberculosis, diphtheria, measles, smallpox, typhoid, and typhus, as well as the "enteric fevers," whose causes were hotly disputed. We now know that dysentery is caused by ingesting food or water contaminated with faecal micro-organisms in environments where sanitation and access to clean water are inadequate. But at the time popular explanations included the "miasma" theory that fevers were caused by foul damps arising from decaying organic material. It was cholera, another consequence of economic progress, particularly the increase in international trade and transport, that "concentrated people's minds." The second, third, and fourth pandemics reached Western Europe in the 1830s, 1850s, and 1860s. Observations on the spread of cholera, as in John Snow's studies around London's Broad Street pump, improved understanding of the causes of enteric disease. His pragmatism (turning off the pump in the face of general disbelief among his peers that water was the source of cholera) has rightly become famous. And the psychological effects of cholera epidemics, which threatened poor and rich people, fostered a collective response. 2

\section{The British sanitary revolution}

As with the Industrial Revolution, Britain also led Europe in the "sanitary revolution," although some ideas came from France. Edwin Chadwick was its champion, neither a medical doctor nor a sanitary engineer but a lawyer who had designed the 1834 Poor Law Amendment Act and who wanted to cut the 
costs of poor relief by preventing a major cause of poverty: acute infectious diseases that killed male breadwinners. Chadwick believed that these diseases were caused by air contaminated as a result of poor urban drainage. He developed a comprehensive solution: new technologies (sewers rinsed by water, his main reason for bringing piped water to individual homes) and the legal and administrative structures needed to build these expensive works. 3

Britain took decades to implement these measures, and they spread only slowly to the rest of Europe, but in the end they had a major effect on mortality. In the Netherlands, for example, the first large municipality with piped drinking water was Amsterdam (1854), followed by Rotterdam and The Hague in the 1870s. By the end of the century around $40 \%$ of Dutch people had piped drinking water, and in the early 20th century sewerage systems covered more than half the population. Between 1870 and 1970 age standardised mortality in the Netherlands fell by almost $75 \%$. An important contribution to this decline was a fall in the numbers of deaths from infectious diseases, including deaths from respiratory tuberculosis (down 15\%), acute respiratory diseases (11\%), and acute digestive diseases (8\%).

Between 1901 and 1970, when a more accurate classification of causes of death was used, a fall in mortality from "diarrhoea and dysentery" accounted for $12 \%$ of the overall decline in mortality in the Netherlands. 4 Similar figures were reported for England and Wales.5

Historical evidence of the effect on mortality of improved water supply and sanitation in Western Europe is limited. Paradoxically, what is probably one of the major breakthroughs in public health lacks the empirical underpinning we now think is essential for evidence based health policy. Not only were the theories incorrect, but empirical evaluations have produced less than convincing results.

Contemporaneous studies were often too crude to produce reliable evidence. More sophisticated studies that retrospectively related mortality to better water supply and sanitation have produced conflicting results, probably because of methodological shortcomings inherent in interventions in natural settings involving whole populations.6 Perhaps the strongest support comes now from poor countries, where evaluation studies, although still beset by methodological problems and inconsistencies, support a substantial effect of improved water supply and sanitation. One review showed that morbidity and total mortality from diarrhoea among children were reduced by about a fifth. Better water quality seems to have had less effect than better water availability or disposal of excreta.7 The global burden of disease study ascribed 1.8 million deaths in 2001 in low and middle income countries to diarrhoeal disease. Unsafe water, sanitation, and hygiene accounted for $88 \%$ of these deaths, indicating that substantial health gains can be achieved by extending the global coverage of adequate water supply and sanitation. 8

\section{The causation paradox}

Improved water supply and sanitation are often held up as exemplars of how best to improve public health, not only in the past but also now and in the future. Of course, it is easy to read too much into a single historical event; and that Chadwick succeeded despite his defective theory of disease causation may have been good luck. Also, diseases whose causal chains can be interrupted by "passive technologies"-such as eliminating faecally contaminated water in the case of "enteric diseases"-may have become rare. Nevertheless, we can still draw three lessons from this tale. Firstly, effective intervention does not always need accurate knowledge of disease causation (the development of sanitary measures largely preceded the germ theory). Secondly, environmental measures may be more effective than changing individual behaviour ("passive" protection through piped drinking water and sewerage systems worked better than educating the public to improve "active" hygienic practices). And 
thirdly, universal measures may be better than targeted measures in reducing health inequalities (better water supply and sanitation reached people at all social levels). These lessons have become part of the "collective consciousness" of public health, 9 and this tale can still inspire us to always search for pragmatic solutions to population health problems, in which health risks are radically removed.

\section{Footnotes}

- Publication of this online supplement is made possible by an educational grant from AstraZeneca

- Competing interests: None declared.

\section{References}

1. Hobsbawn E. The age of revolution: Europe, 1789-1848. London: Weidenfeld and Nicolson, 1962. (Ch. 2 "The industrial revolution.")

2. Porter R. The greatest benefit to mankind: a medical history of humanity. London: HarperCollins, 1997. (Ch. 13 "Public medicine.")

3. Hamlin C, Sheard S. Revolutions in public health: 1848, and 1998? BMJ 1998;317:587-91.

4. Wolleswinkel-van den Bosch JH. The epidemiological transition in the Netherlands [PhD dissertation]. Rotterdam: Department of Public Health, Erasmus University, 1998.

5. McKeown T, Record RG, Turner RD. An interpretation of the decline of mortality in England and Wales during the twentieth century. Popul Stud (Camb) 1975;29:391-422.

6. Van Poppel F, van der Heijden C. The effects of water supply on infant and childhood mortality: a review of historical evidence. Health Transit Rev 1997;7:113-48.

7. Esrey SA, Feachem RG, Hughes JM. Interventions for the control of diarrhoeal diseases among young children: improving water supplies and excreta disposal facilities. Bull World Health Organ 1985;63:757-72.

8. Lopez AD, Mathers CD, Ezzati M, Jamison DT, Murray CJL, eds. Global burden of disease and risk factors. New York and Washington, DC: Oxford University Press and World Bank, 2006.

9. Rosen G. A history of public health (expanded edition). Baltimore, MD: Johns Hopkins University Press, 1993. 